\author{
坂口俊二 藤川 治 \\ 関西鍼尒短期大学 銊尒学臨床教室
}

\title{
Treating Excessive Cold Sensitivity ("Hiesho") with Acupuncture Therapy
}

\author{
Shunji SAKAGUCHI Osamu FUJIKAWA \\ Department of Clinical Acupuncture, Kansai College of Oriental Medicine
}

\begin{abstract}
A b s t r a c t
A 29 year-old female patient with excessive cold sensitivity ("hiesho") was regularly treated with acupuncture therapy. She complained of symptoms from autumn to winter, and her symptoms were also susceptible to changes in temperature. From the oriental medical diagnosis, we found that she exhibited "oketsu" and "suitai". The effects of acupuncture therapy were comprehensively assessed by the Oketsu score, Visual Analogue Scale (VAS) thermograms, etc. We also examined the influence of temperature and menstrual periods on cold sensitivity.

After five months of this therapy (eight times), the Oketsu score and VAS showed a decrease. In addition, this therapy held to elevate the skin temperatures of extremities. It was noted that the temperarure, rather than the menstrual periods, had a stronger influence on VAS. These results were that the acupuncture therapy was effective against the cold sensitivity.
\end{abstract}

Key Words : Hiesho, cold sensitivity, "oketsu" (disturbance of vascular system in the lower abdomen), "suitai" (intoxication by water), Visual Analogue Scale (VAS), thermogram

\section{緒 言}

「㾉え症」は病気の範疇に含まれず、格別に定義 を下さなくても意味が通じ、社会通念として存在 するが、現代医学においては馴染み難い症状のひ とつとなっている。これに対し、随証治療を主と する東洋医学には、その治療体系をみることがで きる。

鍼尒臨床においても「冷え症」は遭遇する機会 の多い不定愁訴のひとつであるが、本症を主訴と して受診するケースは少ない。

今回著者らは、足部の冷えを主訴とした患者の 銊治療を経験したので報告する。
症 例

症 例: 29 歳、未婚女性 証券会社勤務（事務職で勤務歴 8 年）

主 訴: 足関節から足趾が冷えてつらい

(手も冷たいがつらくはない)

愁 訴：肩甲上部の凝り感（運動不足で増悪） 便秘（間隔は隔日）

現病歴：発症は就職直後の21歳頃。冷える部位は 足関節から足趾で、特に足趾は冬場に霜焼けに なり易い。足部が冷えている時には顔面部に火 照りを感じる。発汗立進はみられない。冷えは 秋から冬季に顕著であるが、夏でも足趾尖に冷 
あてはまるところに○印をつけて下さい。

性 別: 男・女

年 齢：10代· 20 代· 30 代· 40 代 $\cdot 50$ 代 $\cdot 60$ 代 $\cdot 70$ 代 $\cdot 80 \cdot$ その他（）

「冷え症」に関する下記の事項についてあてはまるものがありましたら、番号に○印を つけて下さい。

0.「冷え症」だとは思わない。(「冷え症」でない人が○です)

1. 他の多くの人に比べて“寒がり”の性分だと思う。

2. 身体自体が冷えてつらいことがある。

3. 腰や手足、あるいは身体の一部に冷えがあってつらい。

4. 足が冷えるので夏でも厚いクッ下をはくようにしている。

5 ．他の多くの人に比べてかなり厚着する方だと思う。

6. 冬になると冷えるので電気毛布や電気敷布、あるいはカイロなどをいつも用いるよ うにしている。

7. 冷房の効いているところは身体が冷えてつらい。

8.「冷え」のつらさはここ数年続いている。

1 〜 8 と内容が異なりますが、あてはまることがありましたらいくつでも○印をつけて 下さい。

9. 冬には電気毛布や電気敷布をつかっている。

10. クーラーはきらいである。

11. 手足が他の多くの人より冷たい方だと思う。

12. 夏でも厚着のクッ下をはくのが好きである。

13. 厚着をするのは好きである。

14. とくに冬には身体を丸くして寝るクセがある。

15. 冬とか寒い日などは小便がとても近くなる。

16. 夏でも熱い飲み物が好きである。

17. 他の人よりも自分の顔色は青白い方だと思う。

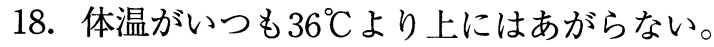

19. 寒い日には関節がこわばったり、痛んだりすることがある。

20. 夏でも手足が冷えることがある。

21. 身体が急にあつくなったり、冷たくなったりすることがある。

22. たえず手足に冷えを感じる。

23. しもやけができやすい。

24. とくに冬には足が冷たくて寝つけないことがある。 
感を伴う。冷える時間帯は勤務中と就寝前。さ らに、冷えは寒冷刺激で顕著となり、疲労や月 経による影響はない。冷えの対策（生活上の工 夫）として、帰宅後の足温浴や就寝時のウール 靴下着用。冷えが特につらい時には靴下にカイ ロを貼って日中を過ごす。これまで冷えに対す る治療経験はない。遺伝的要因としては母が冷 え症である。初診は平成9年11月2日。

月経歴：初潮は14歳。周期は約40日だが、初潮後 より常に整わず、28日になることもある。月経 の持続期間は1週間で月経前・中・後の体調の 崩れはない。平成 9 年には2ヶ月月経がなく婦人 科を受診し、注射にて加療。

生活歴: 平成 7 年より週2日程度、水泳（水中工 アロビクス）に通い、さらに普段から階段を利 用するなど運動を心掛けている。食事は炭水化 物を好み、漬け物、マヨネーズ、酢の物を嫌う。 飲酒・喫煙・コーヒーの飲用なし。睡眠は6 7 時間。

21歳より面皰に対する内服薬を服用している が、現在はコントロール中。

既往歴：低血圧を指摘されることが多い。その他、 卵巣摘出、高血圧、甲状腺機能低下症、副腎疾
患の既往はない。

17歳時に自転車にて乗用車と接触し頭部強打 (意識不明)。頭部挫傷にて20日間入院加療。29 歳時にはバイクにて乗用車と接触（意識清明、 嘔吐無し）したが、左下腿部の打撲のみ。

家族歴：特記事項無し。

身体所見：身長 $164.4 \mathrm{~kg}$ 、体重 $54 \mathrm{~kg}$ 。初診時血圧 (仰臥) は $116 / 74 \mathrm{mmHg}$ 、脈拍60回／分。

1. 診時診察所見: 足関節から足趾の他覚的冷え $(+)$ 、足背 ·後脛骨動脈の拍動 $L=R$ 、腰部お よび下肢（膝窩・下腿・内果）の毛細血管の拡 張 (一)、三陰交穴の圧痛L.R $(+)$ 、大腸俞穴 から下髎穴の反応（圧痛ほか）（）、腎経に相 当する経絡様皮虑線 (一)、YG性格検査による 性格特性はAE型、「冷え症」調査用問診票 $(24$ 項目）【Table.1】による該当は、1、2、3、6、 $7 、 8 、 9 、 11 、 14 、 18 、 20 、 24$ の12項目、脈状 はやや浮・遅 · 大 ·実、舌質淡紅、舌苔薄白 (湿)、㭌大、歯痕 $(+)$ 。

効果判定：鍼治療の効果を評価するため、以下の 評価法を用いた。

1. 瘀血診断基準【Table.2】による瘀血スコア 各項目の判定要領に準じた診察 ${ }^{1}$ )を 1 診時（平

Table.2 瘀血の診断基準

\begin{tabular}{lrrlrrr}
\hline & 男 & 女 & & 男 & 女 \\
\hline 眼輪部の色素沈着 & 10 & 10 & 臍傍圧痛・抵抗 & 左 & 5 & 5 \\
顔面黒色 & 2 & 2 & 右 & 10 & 10 \\
皮膚の甲錯 & 2 & 5 & 正中 & 5 & 5 \\
口唇の暗赤化 & 2 & 2 & 回盲部 & 圧痛・抵抗 & 5 & 2 \\
歯肉の暗赤化 & 10 & 5 & S丈部 圧痛・抵抗 & 5 & 5 \\
舌の紫暗色化 & 10 & 10 & 季肋部 & 圧痛・抵抗 & 5 & 5 \\
細絡 & 5 & 5 & & & \\
皮下溢血 & 5 & 10 & 痔疾 & 10 & 5 \\
手掌紅斑 & 2 & 5 & 月経障害 & & 10 \\
\hline
\end{tabular}

判定 20点以上 非瘀血病態

21点以上 瘀血病態

40点以上 重度瘀血病態 
Fig. 1 冷えの程度を評価するためのVisual Analogue Scale (VAS)

現在、あなたはどの程度「冷え」を感じていますか。

下の横線に「冷え」の程度を縦線で示して下さい。

冷えを全く

感じない

冷えてつらい

あなたは「冷え」を体のどの部分に感じていますか。あてはまるところに○をつけて下さい。

1. 手

2 . 足

3 . 手足

4. その他

Fig. 2 鍼治療によるVASの变化

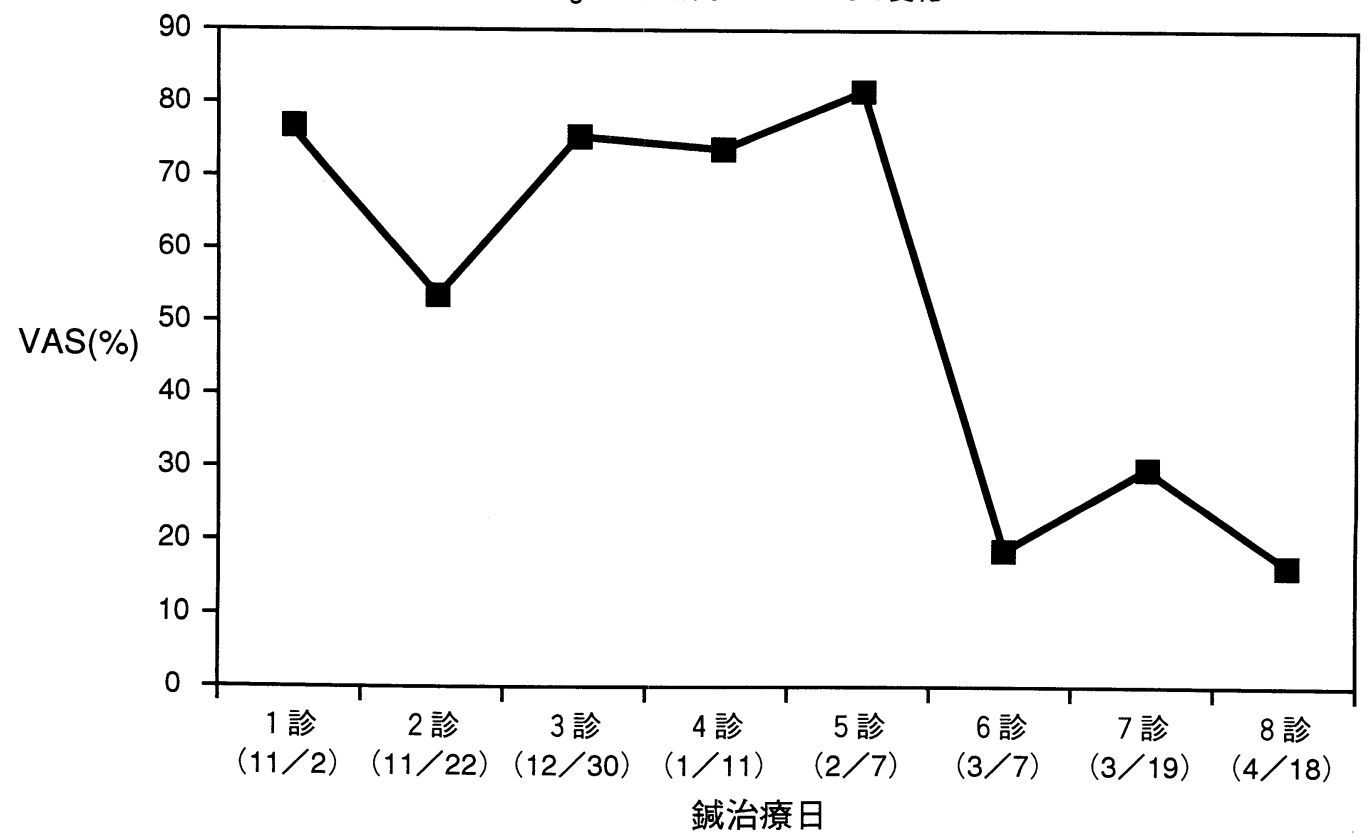

成9年11月2日)、5診時（平成10年2月7日）およ び 8 診時（平成10年4月18日）に行った。

2. Visual Analogue Scale (VAS) による冷えの 自己評価

横型10cmのVAS【Fig.1】を用いて1診時以降、 毎回銊治療前に足部の冷えに対する苦痛度を記 入させた【Fig.2】。

3. サーモグラフィ検査

医療用サーモトレーサ6T66（NECメディカル システムズ(株製）を用いて、瘀血スコア同様、
1 診時、5診時および8診時に手背・顔面部と足 背部の皮膚温を測定した。なお、測定時点は恒 温恒湿室入室直後と 30 分後とした【Fig.3,4】。な お、測定環境は室温 $26 \pm 1{ }^{\circ} \mathrm{C}$ 、湿度 $50 \pm 5 \%$ 、風 速 $0.1 \mathrm{~m} / \sec$ 以下であった。

4. 内省報告（「冷え」日記）

著者らが独自に作成した評価表（「冷え」日 記）に、冷えのVAS、基礎体温、体調の変化な どを患者に記入させた【Fig.5】。さらに、治療 期間中の気象庁の観測データを利用して、外気 
Table. 3 鍼治療による瘀血陽性項目の変化

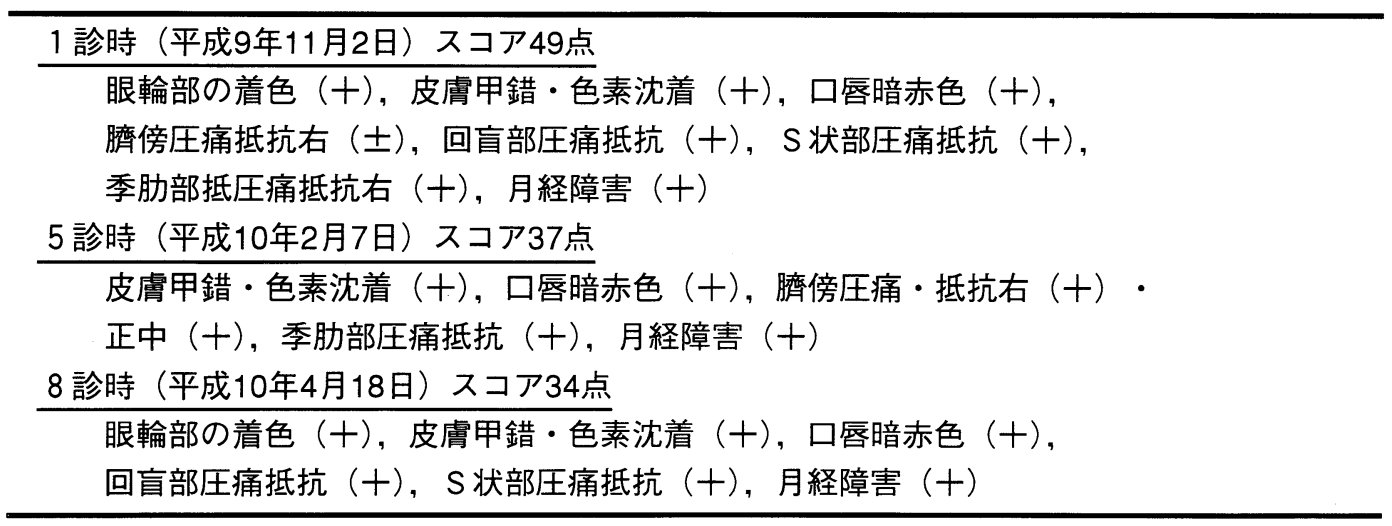

Table. 4 知熱感度測定結果の変化

知熱感度測定結果表【手経】（左側を 1 とした時の右側の比率）

\begin{tabular}{cccccccc}
\hline & 少商 & 商陽 & 中衝 & 膈前 & 関衝 & 少衝 & 少沢 \\
\hline 第1 診 & 0.57 & 1.75 & 0.67 & 1.17 & 0.75 & 2.25 & 0.75 \\
第2 診 & 0.61 & 0.50 & 1.57 & 0.79 & 0.83 & 0.69 & 1.60 \\
第3 診 & 0.24 & 0.55 & 1.55 & 1.15 & 2.07 & 0.50 & 3.33 \\
第4 診 & 0.67 & 0.57 & 0.91 & 4.50 & 0.75 & 0.69 & 0.71 \\
第5 診 & 0.36 & 0.65 & 0.93 & 1.43 & 1.00 & 0.64 & 2.00 \\
第6 診 & 0.90 & 0.50 & 0.91 & 1.18 & 1.27 & 1.00 & 1.00 \\
第7 診 & 0.40 & 0.74 & 0.87 & 1.00 & 0.94 & 0.75 & 0.54 \\
第 8 診 & 0.28 & 0.68 & 1.00 & 0.93 & 1.12 & 0.87 & 1.00 \\
\hline
\end{tabular}

知熱感度測定結果表【足経】（左側を 1 とした時の右側の比率）

\begin{tabular}{cccccccc}
\hline & 隠白 & 大敦 & 厲兌 & 八俞 & 足竅陰 & 内至陰 & 至陰 \\
\hline 第 1 診 & 1.15 & 1.00 & 1.07 & 1.71 & 1.07 & 0.93 & 1.80 \\
第 2 診 & 1.00 & 2.94 & 0.84 & 1.42 & 0.95 & 0.82 & 0.59 \\
第 3 診 & 0.54 & 1.85 & 0.83 & 0.75 & 1.36 & 0.96 & 1.00 \\
第 4 診 & 1.17 & 1.13 & 1.27 & 1.64 & 1.15 & 0.63 & 2.32 \\
第 5 診 & 0.63 & 2.08 & 0.93 & 1.50 & 1.19 & 0.88 & 0.79 \\
第6 診 & 0.71 & 1.05 & 1.14 & 1.18 & 3.85 & 1.17 & 0.56 \\
第7 診 & 0.38 & 1.29 & 1.21 & 0.92 & 1.23 & 1.83 & 0.56 \\
第 8 診 & 0.81 & 1.41 & 1.04 & 1.72 & 2.38 & 2.69 & 1.39 \\
\hline
\end{tabular}


Fig. 3 顔面部・上肢サーモグラムの変化

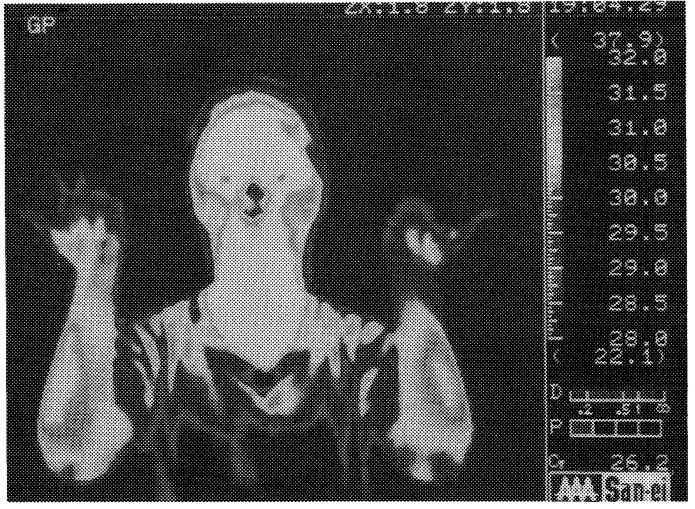

第 1 診（11月） 恒温恒湿室入室直後

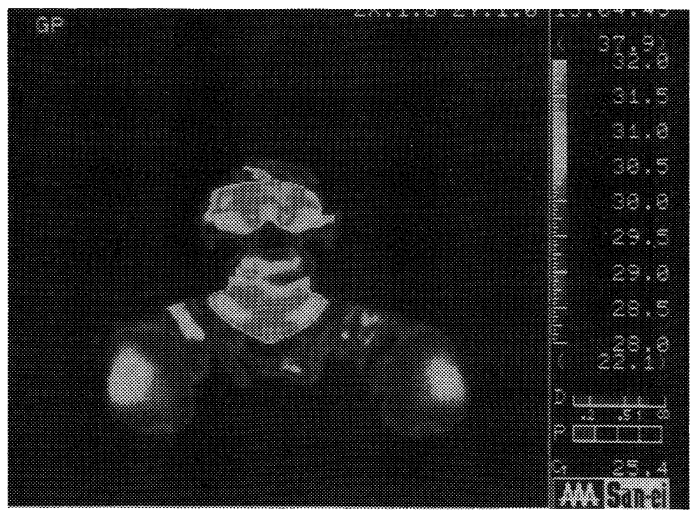

第 5 診（2 月） 恒温恒湿室入室直後

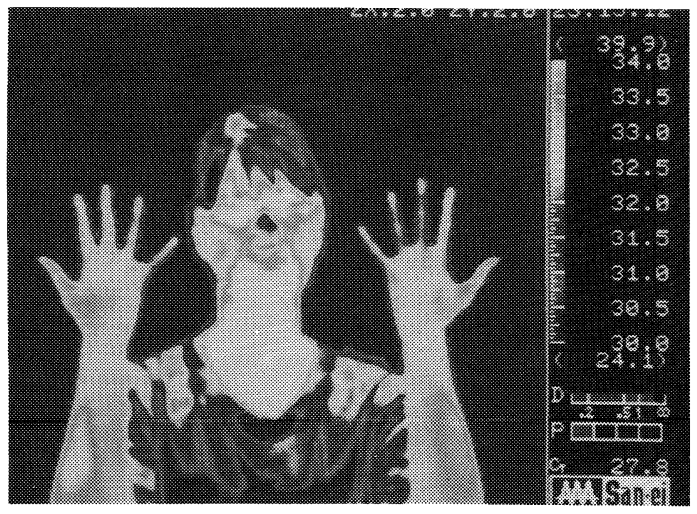

第 8 診（4 月） 恒温恒湿室入室直後

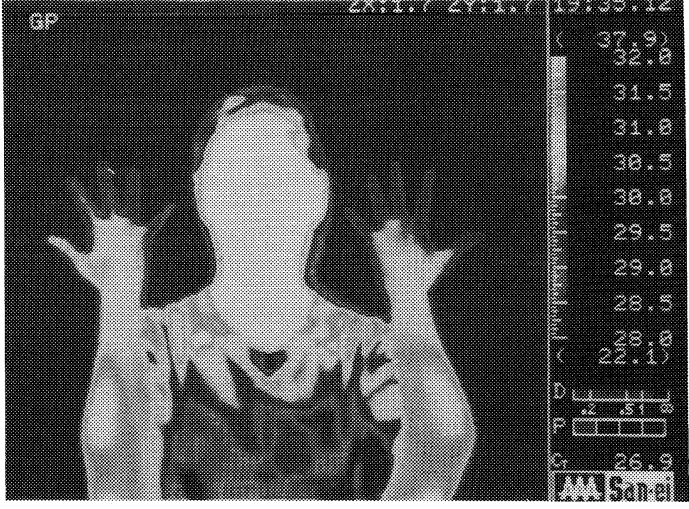

第 1 診（11月） 恒温恒湿室入室30分後

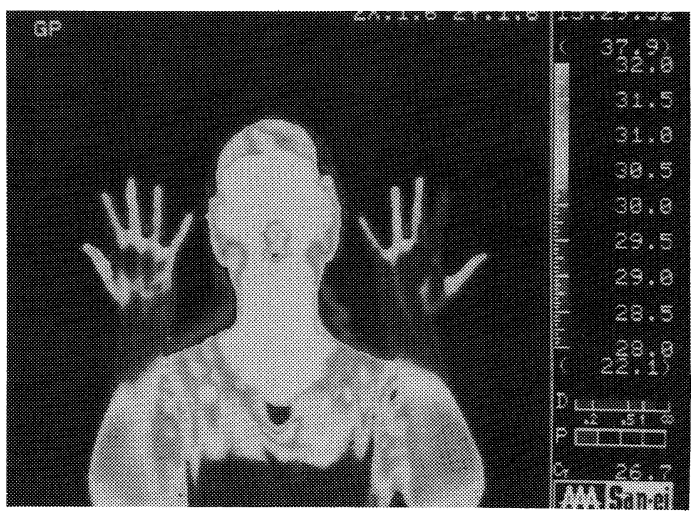

第 5 診（2 月） 恒温恒湿室入室30分後

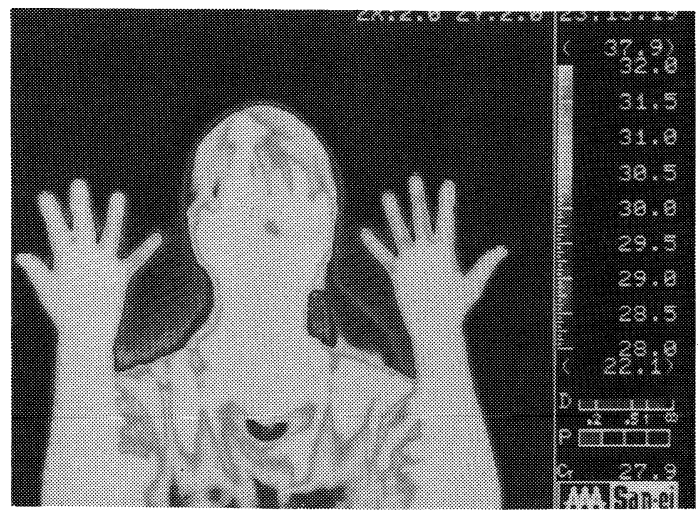

第 8 診（4 月） 恒温恒湿室入室30分後 
Fig. 4 下肢サーモグラムの変化

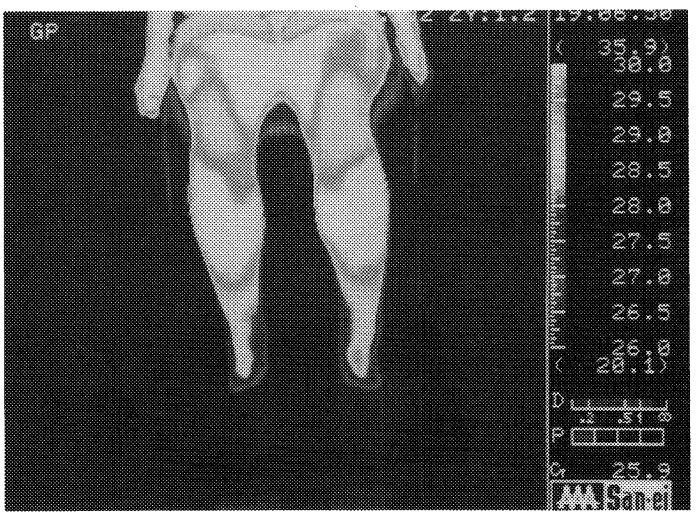

第 1 診（11月）＼cjkstart恒温恒湿室入室直後

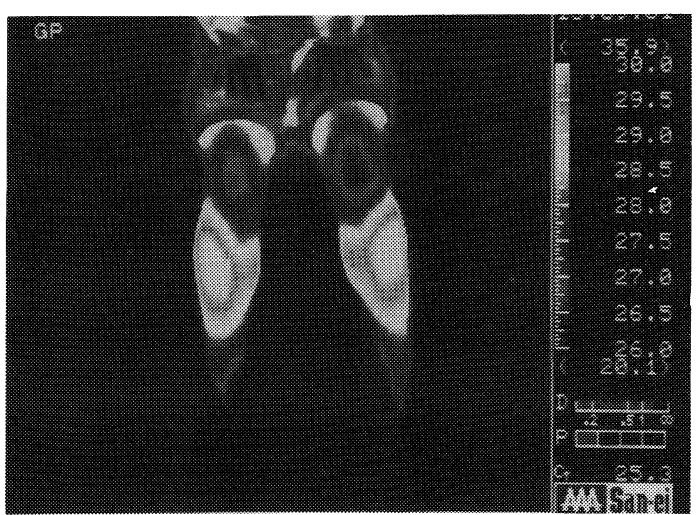

第 5 診（2 月） 恒温恒湿室入室直後

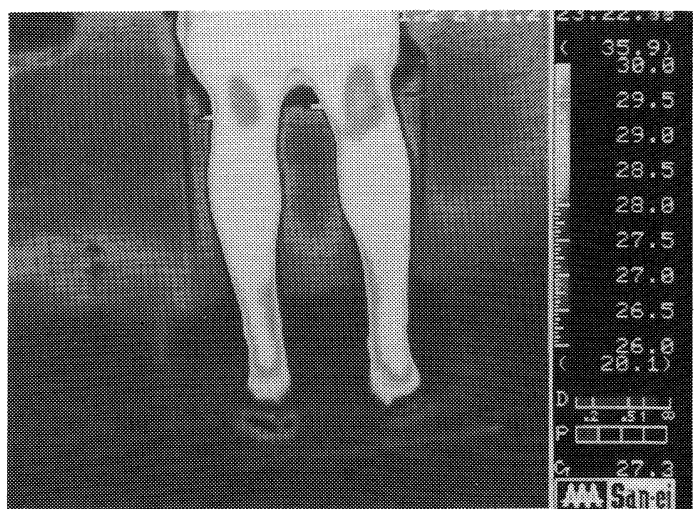

第 8 診（4 月） 恒温恒湿室入室直後

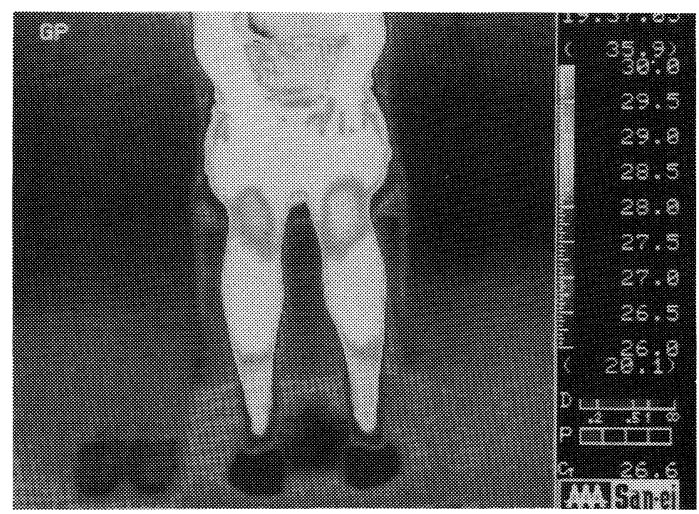

第 1 診（11月） 恒温恒湿室入室30分後

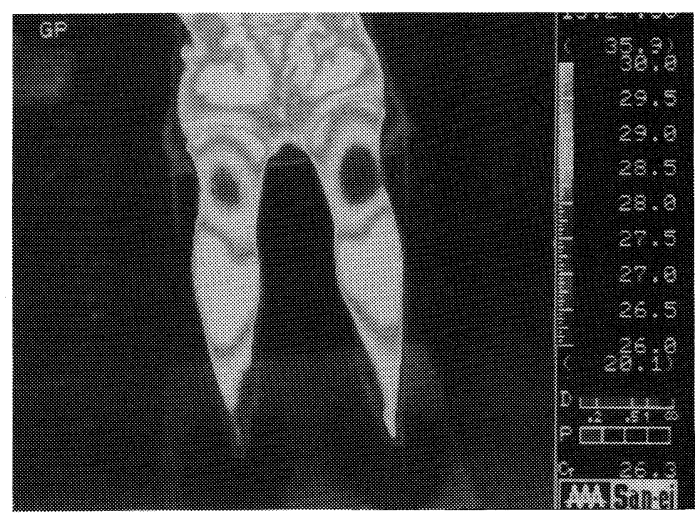

第 5 診 (2 月) 恒温恒湿室入室 30 分後

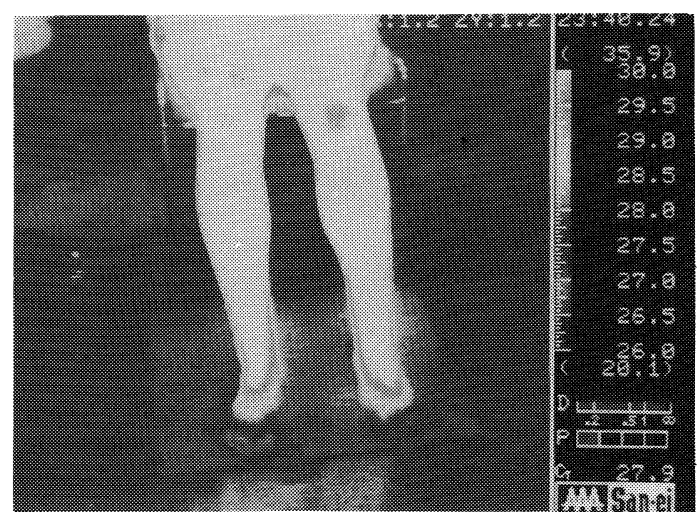

第 8 診（4月） 恒温恒湿室入室30分後 
ป

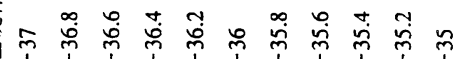
q
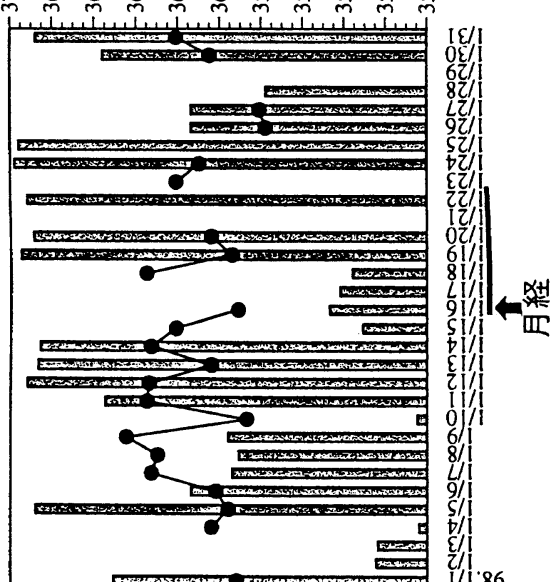

-

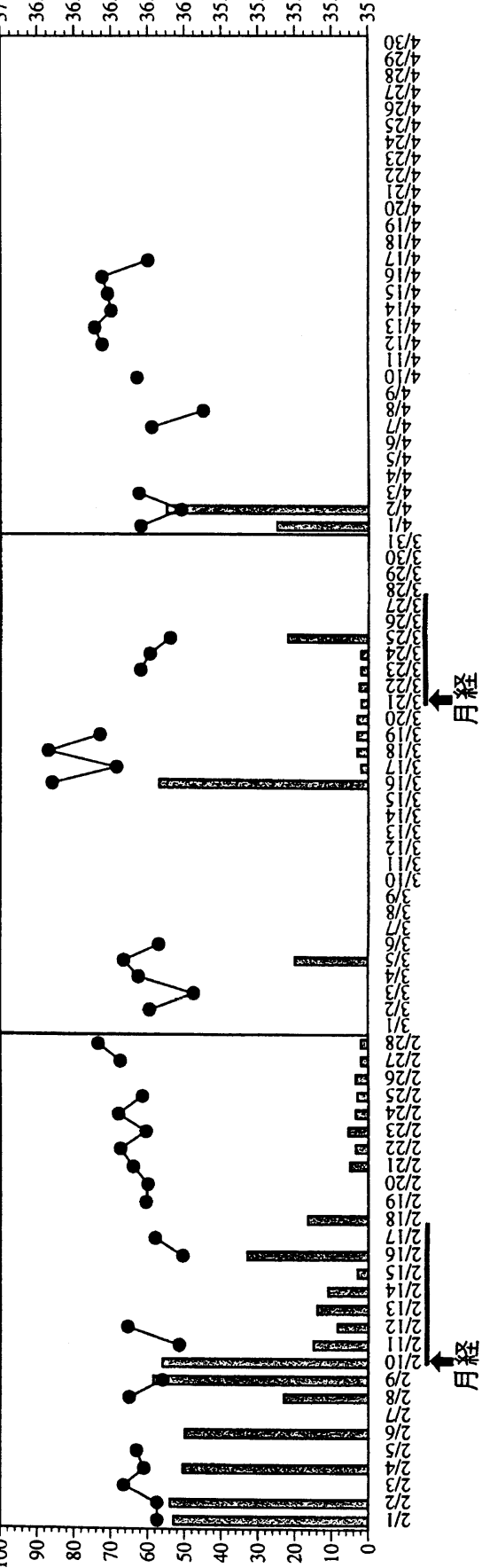

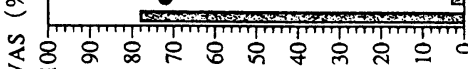
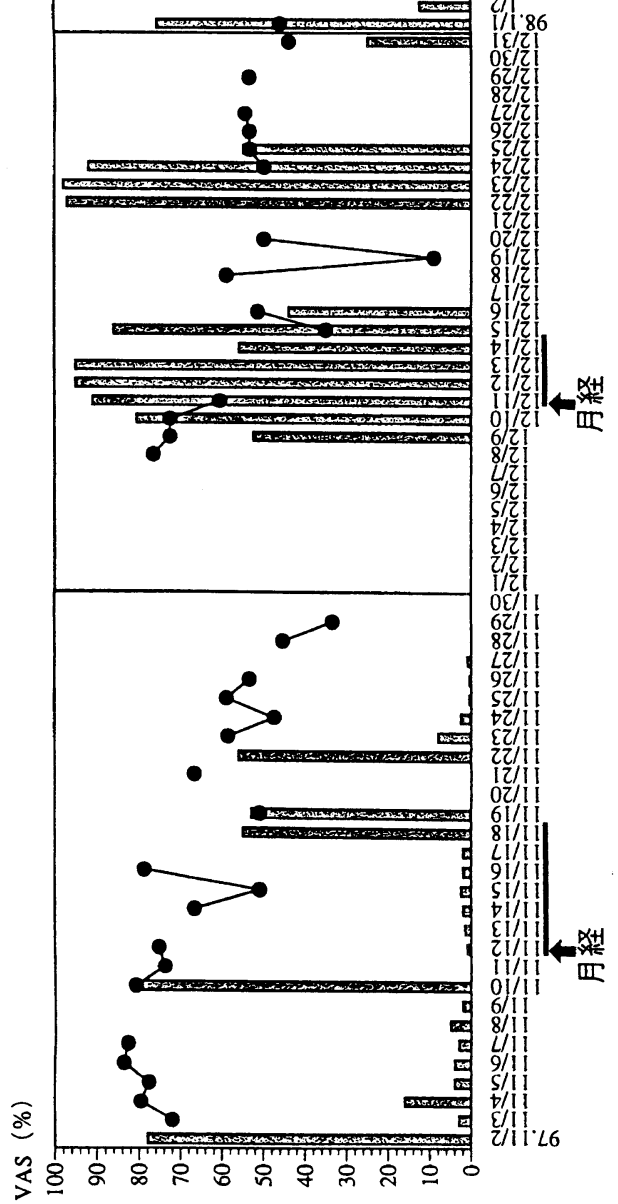

.

Fig. 5 冷えのVisual Analogue Scaleと月経周期 


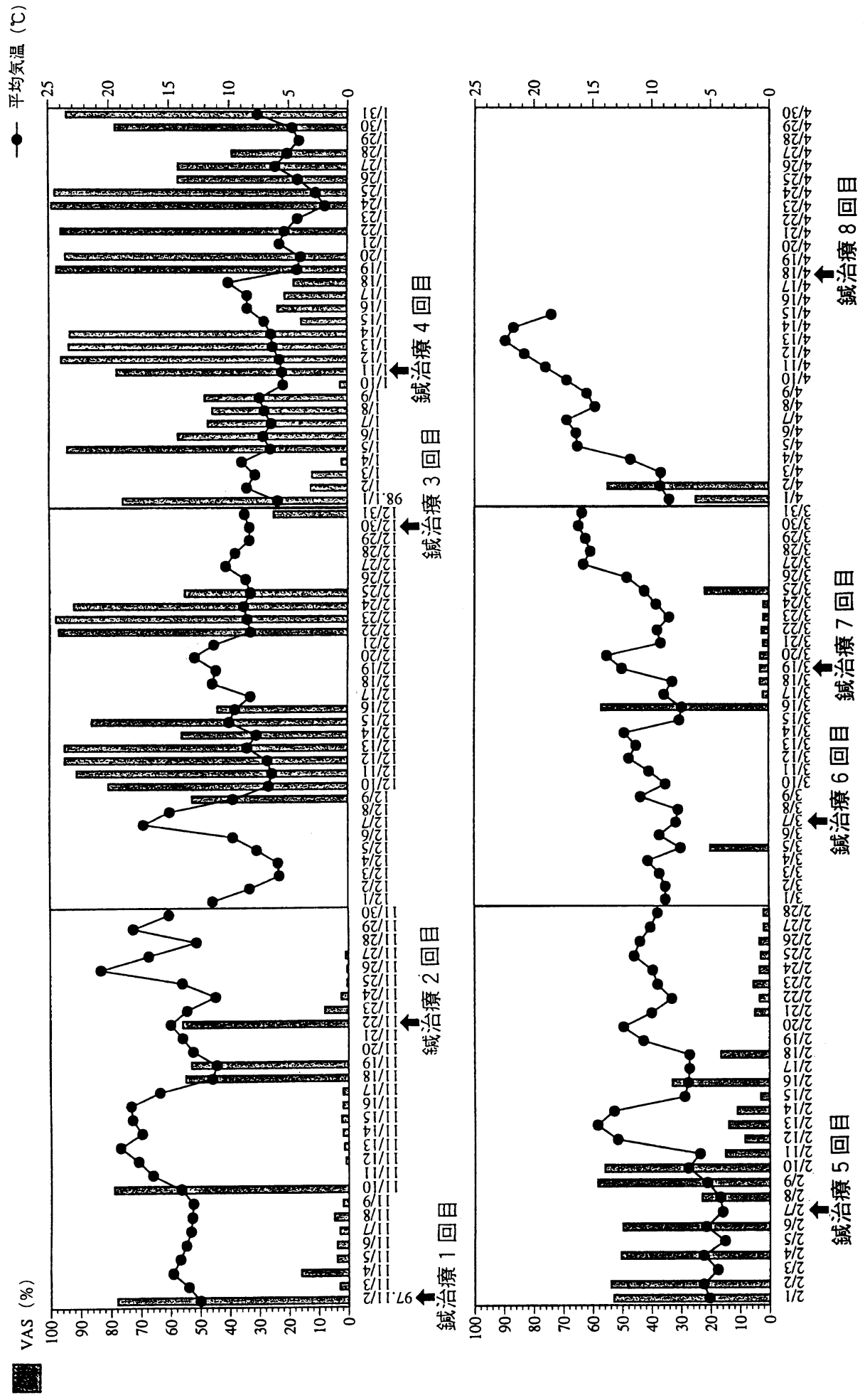

Fig. 6 冷えのVisual Analogue Scaleと外気温（平均気温） 
温と自覚的冷えとの関連についても検討した。 【Fig.6】

治療期間：平成 9 年 11 月 2 日〜平成10年 4 月 18 日の 間に8回。

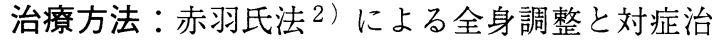
療（置銊10分間を基準）。Table.4に各治療時の 知熱感度測定値の左右比率、Table.5には1診か ら8診時までの治療穴を示した。

\section{治療経過：}

1. 瘀血スコア

瘀血診断基準による瘀血スコアは、1診時 49 点、 5 診時 37 点、 8 診時では34点と治療経 過に伴い減少した【Table.3】。

2. Visual Analogue Scale (VAS) による冷えの 自己評価

各回の鍼治療前のVASは、1診時 $76.5 \% 、 2$ 診以降8診時までは $53.5 \% 、 75.0 \% 、 74.0 \%$ 、 $81.5 \% 、 17.5 \% 、 29.0 \% 、 15.5 \%$ と6診以降顕 著に減少した【Fig.2】。

3.四肢サーモグラム

上肢サーモグラムは、恒温恒湿室入室直後、 1診時には手指部が低温により描出されず、手 背部の温度左右差も顕著であった。5診では 手指から手背部全体が低温域を示したものの 手部全体の温度左右差は認められなかった。 8診には手指部に温度左右差は認められるも のの、手部全体が描出された。恒温恒湿室入 室30分後、各診時とも皮膚温上昇はみられた が、特に8診時は手部全体が高温域を呈し、左
右差も消失した【Fig.3】。

下肢サーモグラムは、恒温恒湿室入室直後、 1診時には足背部から足趾部の低温域を呈し、 5 診時には1診時に比して下腿部の皮膚温がさ らに低下した。8診には下腿部が高温域を呈 し、さらに1診、5診時とも低温域であった足 背部の描出が認められた。しかし、足趾部の 描出はみられなかった。恒温恒湿室入室30分 後、1診、5診時とも足背部より末端部は描出 されなかったが、8診時には足背部が描出さ れた【Fig.4】。

4. 内省報告（「冷え」日記）

治療開始（11月）から治療終了（4月）ま での各月の平均気温は、 11 月が $14.8^{\circ} \mathrm{C} 、 12$ 月 が $13.2^{\circ} \mathrm{C}$ 、以下、 $6.1{ }^{\circ} \mathrm{C} 、 8.1^{\circ} \mathrm{C} 、 10.7^{\circ} \mathrm{C}$ 、 $15.9^{\circ} \mathrm{C}$ であり、Fig.6に示すように、平均気温 が最も低かった1月のVASは他の月に比して 高く、さらに変動も大きかった。しかし、2 月中旬以降、外気温は11月から12月に比して 低いにもかかわらず、VASが顕著に減少して いた。

Fig.5に示した通り、基礎体温は概ね2相性 であるが、月経周期は11月以降29日、36日、 22日、25日、39日と一定しなかった。しかし、 内省報告から月経前・中・後の冷えの増悪、 体調の不調などの訴えなどはみられなかった。 また、愁訴であった便秘については、内省報 告から6診以降解消傾向にあった。

Table. 5 「冷え症」に対する鍼治療空

第 1 診 上仙, 足三里, 陰陵泉

第 2 診 志室 $(R)$ ，肓門 $(\mathrm{L})$ ，外陵，関元，足三里，陰陵泉

第 3 診 大横 $(\mathrm{L})$, 外陵, 承山（単刺)，足三里，陰陵泉，三陰交，仙腸関節部の硬結・圧痛部 ならびに八髎穴

第 4 診 志室, 外陵 (L)，陰陵泉，上巨虚，支溝（L)

第 5 診 志室, 次髎, 委中, 肓俞 $(R)$, 外陵 $(\mathrm{L})$, 足三里, 陰陵泉

第 6 診 志室, 次髎, 委中, 外陵, 関元, 足三里, 陰陵泉

第 7 診 志室, 次髎, 委中, 外陵, 関元, 足三里, 陰陵泉

第 8 診 肓門，次髎，委中，外陵，関元，足三里，陰陵泉 


\section{考 察}

冷え症は女性に多い不定愁訴の一つで、本人に とっては相当に苦痛であり、身体的、精神的さら に社会的にも重大な問題を含むものである。最近 では、職場環境や冷房等の生活環境の変化で人工 的な冷えを増強する傾向にある3)。

本症例では、まず過去の文献 $4-5)$ から冷え症 の病態把握のメルクマールとなる項目を参考に問 診を行うこととした。発症年齢、冷える部位・季 節・時間帯、冷えの日内変動や月経の影響、さら に冷えの自己対策や遺伝的素因などについて詳細 に問診を行った。冷え症と月経の関連については、 冷え症者の多くは月経障害を伴っているという報 告がある ${ }^{6)}$ 。生活歴では偏食の有無、運動状況、 嗜好などについて問診することで、治療以外の生 活指導にその情報を生かすことが出来ると考える。

既往歴では、血圧の不安定の有無、卵巣摘出、 甲状腺機能低下症ならびに副腎疾患の有無につい て特に問診する必要がある。これらの項目の存在 は、冷え症の病態が続発性 (二次性) であること を示し、この場合は原疾患の治療が先決であり、 適応と鑑別のポイントでもある。さらに冷え症で は、情動障害などをきっかけに心因性に皮膚の冷 覚異常を引き起こしていると推察できるものを心 因性自律神経症 7 ) として分類している。

これまで、銊尒臨床研究では各疾患の補助的診 断法の一つとして、CMI健康調査表を多用してき た。しかし、本表は質問項目が多く調査に時間を 要し、さらに質問がかなりプライバシーに踏み込 んだものであることから、今回は短時間で実施可 能なYG性格検査を採用した。その結果、本症例 のプロフィール判定はAE型、性格特性は劣等感 大、非協調的、非活動的、思考的内向、社会的内 向などであった。AE型とは、基本的にはE型であ るが、正常範囲との中間的存在である ${ }^{8)}$ 。悪い面 が中へこもるとノイローゼ傾向に陥りやすく、悪 化すると無気力、受動的で絶えず何かに悩まされ ており、自己の弱さのために、ノイローゼや問題 を起こしやすいことになる。特に非活動的な人は ノイローゼ傾向が強いとされている。すなわち、 本症例は普段は平凡、性格特性も平均的であるが、 ストレスなどが誘因となって安定性を失った際に
はノイローゼを起こしかねない夕イプといえる。 よって、本結果と冷えとの関連は、性格特性上、 情緒不安定はみられないものの、寒冷刺激などが 誘因となって普段の平凡性が崩れた時には、心因 性に冷えを引き起こす可能性を示唆するものであ る。また、冷え症の特徴と冷えの程度を知るため に、寺澤の「冷え症」の調査用問診票9)に著者 らが項目を加えて再編した寺澤変法を用いた。そ の結果、24項目中12項目に該当したことから、冷 えの程度がかなり強いものであると判断できた。

1診時の診察所見としては、他覚的冷えの有無 判定、血圧測定（毎回治療前に実施）を行い、さ らに末梢循環不全 (バージャー病、閉塞性動脈硬 化症、レイノー病など）がないかをチェックする ために、足背ならびに後脛骨動脈拍動の左右差の 有無を確認した。さらに、東洋医学的特徵とされ る腰部抢よび下肢 (膝窩・下腿・内果) の毛細血 管の拡張は、いわゆる細絡を示し、女三里と称さ れる三陰交穴は女性疾患共通の診断点であり、さ らに大腸俞穴〜下髎穴の反応や腎経に相当する経 絡様皮膚線の有無は、冷え症の重要な診断ポイン ト10)とされている。また、舌象の異常は病状の変 化を反映するものとされている。

以上の多面的調査から、本症例の冷え症の特徽 を総合的に考察すると以下のようになる。

1. 性格特性において情緒不安定はみられない ものの、ストレスなどで普段の平凡性が崩れた際 には、心因性に冷えを起こす可能性がある。2 . 足関節から足趾の冷え感が強く、サーモグラフィ による他覚的検査においても該当部の温度低下が 認められる。3. 東洋医学的には、瘀血診断基準 による瘀血スコアが高值で、さらに舌に㭌大なら びに歯痕がみられることから病態として瘀血・水 滞証と考えられる。4.月経周期は一定していな いものの（基礎体温は2相性）、月経の前・中・後 での冷えのVASの増悪ならびに体調の崩れは認め られない。 5 . 冷えのVASと外気温の関係から VASは外気温が大きく低下する12月中旬〜2月中 旬は高値を示すとともに変動も大きいが、2月中 旬以降、VASは顕著に低值を示す【Fig.6】ことか ら、冷えの自覚に外気温が大きく関係している。

以上の特徴をもつ冷え症に対する鍼治療の方針 
は、全身調整と足の冷えに対する対症的治療によ る東洋医学的組み立てに基ついて行った。全身調 整には、井穴の知熱感度測定結果（左右差）に基 づく背部俞穴への補瀉刺激、いわゆる赤羽氏法を 用いた。各治療時の知熱感度測定值 (左右比率) はTable.4に示したが、各回とも左右差が2倍以上 あるものを基準として変調経を判断し、さらに治 療日の問診等の結果を鑑み、2倍以下であっても 必要と判断した場合には調整経とした。1診から8 診までの傾向としては、肺・大腸・膀胱経の出現 頻度が高く、膀胱経を除いては冷え症に特徴的な パターンとは判断し難いが、肺・大腸経のパター ンは、症例の愁訴である便秘や2診時以降にみら れた皮膚の湿疹などを反映している11）ものと理解 できる。対症的治療についてはTable.3の通り、症 例の㾉血関与度は非常に高く（1診時スコア49点 は重度瘀血病態)、駆疙血を目的に治療を組み立 てることを中心に考えた。しかし、冷え症の原因 を東洋医学的にみた場合、血虚（疼血など）が主 体となることが多いが、他に気虚や水滞で起こっ てくる12)ことも考えられる。著者らは、舌に見ら れた㭌大、歯痕の所見から、水滞の内在を重視し、 瘀血を動かすために水を逐う13）ことに重点を置く ことにした。3診では特に便秘に対する配穴を重 視しているが、4診以降は積極的に駆疼血穴 ${ }^{14 ） を ~}$ 中心にした配穴を行った。5診時には疼血スコア が初診時より12点減少の37点、8診時には34点と なった。しかし、8回の銊治療で月経異常を改善 することが出来なかったことが、更なるスコア減 少に繋がらなかったと考える。

VASは近年、ソフトデータとして見直され、現 代医学においては癌患者のQOLの評価にも使われ ている15)。鍼尒治療では、その効果を患者の自覚 に頼ることが多く、その自覚を視覚および他覚的 に評価する方法としてVASが多用されている。今 回は最もバイアスがかかり難いとされる横型 $10 \mathrm{~cm}$ のカテゴリーを持ったGraphic Racting Scale（GRS） 15）を用いて、銊治療による冷えの苦痛度の変化 を検討することとした。毎回銊治療前に行った VASは、3〜 診時（12月下旬～2月上旬）に高值 を示したが、6診時（3月上旬）以降顕著に減少し た。Fig.6の時系列データからも、1月以降の外気
温低下がVASに最も影響を与えていることがわか る。しかし、2月下旬以降のVASの減少は外気温 の要因が大きいが、2月～3月の平均気温が11月よ り 4 6 ${ }^{\circ} \mathrm{C}$ 低いことを考慮すると、VASの減少は単 に外気温のみならず、継続的な鍼治療の効果を反 映しているものと考えられる。

サーモグラムの測定時点は断続的であり、時系 列デー夕であるVASとの関連をみるのは困難であ るが、5診時の下肢サーモグラムは1診時と比して 足趾部の低温域は変わらないものの、下腿部の皮 膚温はさらに低下していることと、1診時に比し て 5 診時は外気温が $8.5^{\circ} \mathrm{C}$ 低く、VASが5\%上昇して いることから、VASと外気温ならびにサーモグラ ムは関連性が高いと考えられる。

サーモグラム測定時点と同様に判定した瘀血ス コアとVASとの関連については、5診時には1診時 に比してスコアは12点減少したものの、8診時は5 診時に比して3点の減少にとどまった。8診時には VASの顕著な減少ならびに下肢皮膚温の上昇が認 められたにもかかわらず、それらに比して疼血ス コアの減少の程度は小さかった。

月経とVASとの関連については、基礎体温の継 続的測定により性周期（低温期から高温期への移 行、すなわち排卵の有無）を確認することは冷え のみならず、様々な愁訴との関連16）を把握する上 でも重要なことと考える。月経時に冷え症が認め られたり、増悪したりすることが多いが、この時 期は卵巣性ステロイドの血中值が変動する時期で あり、自律神経の不安定な人では本症が出現しゃ すいと考えられている17)。患者自身、1 診時問診 で月経と冷えとの関連を否定しており、さらに Fig.5においても月経とVASとの間に一定の傾向を 見出すことはできなかった。ただ、月経周期は不 安定なことから、情動的刺激や環境の変化などに 敏感に影響を受けるタイプと考えられる。

以上のように、冷え症に対する銊治療の効果判 定を行ったが、測定時点でのVASとサーモグラム は相関傾向を示したが、瘀血スコアとの関連を明 確に見出すことはできなかった。水を逐うことで 瘀血を駆逐することを目的としたが、舌象の変化 は1度しか認められず、最終的には駆瘀血が不十 分であったと思われる。しかし、気温とVASとの 
間に関連があったことを鑑みると、本症例の病態 の主体は気象要因に関係した冷覚過敏症と判断で きる。しかし、YG性格検査の結果から、本症例 にとっては気象要因（外気温の低下）そのものが 直接的に冷覚を過敏にしているのみでなく、スト レスのひとつとなってさらに症状を助長している ものと考える。

よって治療方針については、冷え症状が冬場の み顕著になるため、今後は1月～2月の銊治療の頻 度を多くしたり、炎治療を併用するなどの工夫が 必要と考えられた。さらに局所的な症状のみにと らわれず、全面的な分析をもってアプローチをす ることが重要であると考える。

\section{結 語}

足関節から足趾の冷えを主訴とする患者（29歳、 女性）に対して、継続的に鍼治療を行った。

1. 冷えは秋から冬季にかけて顕著で、冷える時 間帯は勤務中と就寝前であった。また、冷えの 程度は寒冷刺激に大きく影響し、冷えがつらい 時には靴下にカイロを貼ったり足温浴をするな ど生活上の工夫をしていた。

2. 問診、視診および触診などの東洋医学的所見 より、患者の病態を瘀血・水滞証と判断し、主 として水を逐うことで血を動かすことを目的と した。

3. 治療開始5ヶ月後（鍼治療8回）には、疼血ス コアが 1 診時の 49 点から 34 点に減少し、VASも 5 診以降顕著に減少し、1 診時の約 $14 \%$ となっ た。

4. 継続的な銊治療により、上・下肢の皮膚温は 上昇し、左右差が少なくなる傾向を示した。

5.月経周期ならびに持続期間は整わない（基礎 体温は2相性を示す）が、そのことがVASに与 える影響は殆どなく、VASの改善には外気温の 変化が大きく関与していたことから、本症例の 主体は冷覚過敏症であり、それを助長する要因 として不安定な性格特性が考えられた。

6. 冷覚過敏症が主体である患者に対して、東洋 医学的見地より継続的に銊治療を行うことの有 用性が示唆された。

\section{文 献}

1）寺澤捷年, 篠田裕之, 今田屋 章, et al : 瘀 血証の症候解析と診断基準の提唱，日本東洋 医学雑誌, 34（1）, 1-17, 1983.

2 ) 赤羽幸兵衛：知熱感度測定による鍼炎治療法, 医道の日本社, 東京, 1-41, 1985.

3 ) 村山ヒサ工, 佐藤 悦, 高橋美恵子：女性にお ける冷え症の実態〈文献的考察〉, 漢方の臨 床, 42（5）, 560-583, 1995.

4 ) 近藤正彦, 岡村 靖 : 冷え性の病態に関する 統計学的考察, 産婦人科学会雑誌, 39 (11), 2000-2004, 1987.

5 ）全日本銊炎学会東京地方会学術部：愁訴から のアプローチ（11）七、冷えとのぼせの鍼炎, 医道の日本, 591, 54-64, 1993.

6 ）川田信昭, 吉谷徳夫：産婦人科疾患に対する 基本的随証療法の試み-月経困難症, 更年期不 定愁訴, および冷え症を中心として-, 新薬と 臨床, 38（7）, 168-174, 1995.

7 ) 加藤順三, 佐藤正仁：冷え症について-現代医 学から, 現代東洋医学, 2 (4), 11-15, 1981.

8 ) 日本臨床心理学会：心理テスト・その虚構と 現実, 株式会社現代書館, 東京, 204-244, 1984.

9 ) 坂口俊二, 川本正純, 藤川 治：「冷え症」の 定義の明確化に向けて一「冷之症」調査用問 診票（寺澤変法）の有用性の検討一, 関西鍼 尒短期大学年報, 13, 58-63, 1997.

10）吉元昭治：「冷え症」の針尒治療, 現代東洋 医学, 2 (4), 28-36, 1981.

11）代田文誌：銊炎治療基礎学, 医道の日本社, 東 京, 43-45, 1988.

12）勝田正泰 : 冷え症の漢方治療概論, 現代東洋医 学, 2 (4) ,6-10, 1981.

13）真鍋立夫：瘀血証の治療の時期と取穴及び方 剂, 瘀血研究, 9, 107-110. 1989.

14）真鍋立夫：鍼炎治療における疼血処理，その 診断と選穴及び手技, 疼血研究, 8, 33, 1989.

15）七堂利幸：鍼尒臨床効果判定で使うVisual Analogue Scale, 全日本銊尒学会雑誌, 46 (1), 7-13, 1996.

16）芽島江子：性周期に伴う愁訴，産婦人科の実 際, 41（7）, 959-965, 1992. 
17）桑原惣隆：冷え症, 産婦人科の実際, 39（5）,

697-700, 1990.

\section{要旨}

足部の冷えを主訴とする29歳女性患者に対して、継続的に銊治療を行った。患者の症状は秋から冬季に かけて顕著で、特に寒冷刺激に左右された。東洋医学的には瘀血・水滞病態とみられた。鍼治療による効 果は、瘀血スコア、VAS、サーモグラムなどから総合的に判定した。さらに、外気温ならびに性周期が冷 え症状に及ぼす影響についても検討した。

治療開始5ヶ月後（8診終了時）には、1 診時に比して瘀血スコアならびにVASの減少、さらにサーモグ ラムによる皮膚温上昇が認められた。

性周期に比べて外気温がVASに与える影響が顕著に認められたことから、症例の主体は冷覚過敏症と考 えられ、本症に対して鍼治療は奏効することが示唆された。

キーワード : 冷え症, 痁, 水滞, Visual analogue scale (VAS), サーモグラム

\section{厚生大臣認定 東京

理 事 長

校長平川信代

医療専門課程 本 科

はり・きゅう・あん摩・マッサージ・指圧科 3 年制、高卒以上 医療専門課程 専科

あん摩・マッサージ・指圧科 3 年制、高卒以上

福祉専門課程 介護福祉科

2 年制、高卒以上
人学案内書
1000 円
（下共）

T 104 東京都中央区八丁堀 $2-29-15$

T E L O 3（３５５1）5751 (地下鉄日比谷線八丁堀駅徒歩 1 分·J R 京葉線八丁㙋駅徒步 3 分) 